\begin{tabular}{cc}
\hline JOURNAL PHYSICAL \\
HEALTH RECREATION \\
Volume 1 Nomor 1; November 2020 \\
\hline
\end{tabular}

\title{
HUBUNGAN KOORDINASI MATA-TANGAN DENGAN KETEPATAN PUKULAN FOURHAND TENIS MEJA MAHASISWA PKO FIK UNIMED
}

\author{
Rizkei Kurniawan', Yoki Afriandy Rangkuti ${ }^{2}$ \\ Program Studi Pendidikan Jasmani, Fakultas Keguruan dan Ilmu Pendidikan, Universitas \\ Samudra, Indonesia \\ E-mail: RIZKEI@unsam.ac.id ${ }^{1}$, yokikenshi@unsam.ac.id ${ }^{2}$
}

\begin{abstract}
ABSTRAK
Penelitian ini bertujuan untuk mengetahui apakah koordinasi mata-tangan berhubungan terhadap ketepatan pukulan fourhand tenis meja pada mahasiswa PKO fakultas ilmu keolahragaan UNIMED. Ketepatan pukulan dipengaruhi oleh beberapa faktor seperti, koordinasi mata tangan, fleksibelitas pergelangan, motivasi latihan dan lain sebagainya, berdasarkan hasil pengamatan penulis, mahasiswa yang mengikuti mata kuliah pilihan tenis meja tidak semua menguasai teknik dasar permainan tenis meja seperti forehand. Ketika bola dipukul dengan forehand stroke, bola tidak mengarah sesuai sasaran dan seperti tidak terkontrol. Seorang pemain yang bisa memaksimalkan koordinasi mata-tangan, akan mampu mengontrol bola dengan baik dan dapat mengembalikan bola dalam posisi-posisi sulit. Kemampuan pukulan forehand dipengaruhi oleh koordinasi mata-tangan. Pemain yang mempunyai koordinasi mata-tangan yang baik akan menghasilkan pukulan forehand yang tepat sasaran. Pada hipotesis dikatakan bahwa terdapat hubungan yang signifikan antara koordinasi mata-tangan $(\mathrm{X})$ dengan ketepatan pukulan forehand tenis meja (Y) pada mahasiswa PKO Unimed. Berdasarkan hasil pengujian hipotesis mengenai hubungan antara kedua variabel terbukti dimana terdapat hubungan yang signifikan, hasil koefisien korelasi (ry.x) sebesar 0,4081 dengan koefisien determinasi sebesar 16,66\%. Hal ini berarti koordinasi mata-tangan mempunyai hubungan yang cukup kuat. Koordinasi mata-tangan juga dapat mempengaruhi ketepatan pukulan forehand tenis meja sebesar 16,66\% sedangkan $83,34 \%$ ditentukan oleh variabel yang lain. Dengan memiliki kemampuan koordinasi mata-tangan yang baik maka ketepatan pukulan forehand tenis meja akan baik pula.
\end{abstract}

Kata kunci: Fourhand, Tenis Meja, dan Koordinasi Mata-Tangan

\section{ABSTRACT}

This study aims to determine whether eye-hand coordination is related to the accuracy offourhand table tennis in PKO students of the UNIMED sports science faculty. The accuracy of the strokes is influenced by several factors such as hand eye coordination, wrist flexibility, training motivation and so on. Based on the author's observations, not all students who take table tennis elective courses master the basic techniques of table tennis games such as forehand. When the ball is hit 
with a forehand stroke, it does not aim at the target and appears to be out of control. A player who can maximize eye-hand coordination, will be able to control the ball well and can return the ball in difficult positions. The ability of the forehand is affected by eye-hand coordination. Players who have good eye-hand coordination will produce a forehand that is right on target. In the hypothesis it is said that there is a significant relationship between eye-hand coordination $(X)$ and the accuracy of table tennis forehand $(Y)$ in PKO Unimed students. Based on the results of hypothesis testing regarding the relationship between the two variables, it is proven that there is a significant relationship, the result of the correlation coefficient (ry.x) is 0.4081 with a determination coefficient of $16.66 \%$. This means that eye-hand coordination has a strong enough relationship. Eye-hand coordination can also affect the accuracy of table tennis forehand strokes by $16.66 \%$, while $83.34 \%$ is determined by other variables. By having good eye-hand coordination skills, the accuracy of table tennis forehand strokes will be good too.

\section{Keywords: Fourhand, Table Tennis, and Eye-Hand Coordination}

\section{PENDAHULUAN}

\section{Permasalahan Penelitian}

Peningkatan kesegaran jasmani dan berprestasi di bidang olahraga merupakan salah satu sasaran dalam usaha membangun manusia Indonesia seutuhnya. Hal ini dibuktikan dengan masuknya cabang ini dalam kurikulum di sekolah dan universitas. Hal ini berarti bahwa melalui Pendidikan Jasmani, Kesehatan dan Rekreasi Olahraga dan Pendidikan Kepelatihan Olahraga merupakan usaha nyata yang dilakukan oleh pemerintah melalui perguruan tinggi yaitu adanya Fakultas Ilmu Keolahragaan dengan Jurusan Pendidikan Jasmani dan Olahraga serta tersedianya fasilitas olahraga sebagai tempat para mahasiswa untuk dapat melakukan latihan dan pembinaan.

Saat sekarang ini banyak olahraga yang mendapat perhatian serius dalam proses pembinaan. Salah satu cabang olahraga yang mendapat perhatian yang serius dalam pembinaannya adalah permainan tenis meja. Permainan ini juga sangat menarik dan dapat dimainkan di dalam rumah dengan peralatan yang relatif murah, serta tidak membutuhkan tempat yang luas.

Perkembangan olahraga tenis meja pada saat ini mengalami kemajuan yang cukup pesat. Hal tersebut dapat dilihat dari antusiasme masyarakat dalam mengembangkan olahraga tenis meja yaitu dengan bermunculan perkumpulan-perkumpulan tenis meja di tiap daerah baik dalam pembinaan usia pelajar maupun usia dewasa.

Melihat perkembangan demikian cabang olahraga tenis meja sekarang cenderung menginginkan kearah prestasi. Untuk meningkatkan keterampilan bermain tenis meja, dibutuhkan kelengkapan kondisi fisik agar mampu mendapatkan prestasi lebih tinggi, di samping penguasaan teknik, taktik serta strategi. Seperti yang dikemukakan oleh Mochamad Sajoto, "pembinaan kondisi fisik dalam olahraga bahwa kalau seseorang atlit ingin berprestasi harus memiliki kondisi fisik seperti: Kekuatan (strength), daya tahan (endurance), daya ledak otot (muscularpower), kecepatan (speed), koordinasi (coordination), kelentukan (fleksibility), kelincahan (agility), 
keseimbangan (balance), ketepatan (accuracy), reaksi (reaction).

Prestasi atlet cabang olahraga tenis meja baik dalam pesta olahraga nasional maupun internasional menjadi kurang maksimal, seseorang yang ingin berlatih tenis meja menjadi lebih lama dalam berlatih tenis meja, sehingga pemain tenis meja masih perlu dibina dan diarahkan untuk diberikan latihan-latihan kondisi fisik, antara lain koodinasi mata-tangan serta ditunjang keterampilan penguasaan teknik dasar seperti melakukan pukulan forehand.

Hal ini juga terjadi pada mahasiswa FIK UNIMED. Penulis mengamati proses perkulihan mahasiswa jurusan Pendidikan Kepelathan Olahraga yang mengambil mata kuliah pilihan tenis meja. Berdasarkan hasil pengamatan penulis, mahasiswa yang mengikuti mata kuliah pilihan tenis meja tidak semua menguasai tekhnik dasar permainan tenis seperti forehand. Ketka bola dipukul dengan forehand stroke, bola tidak mengarah sesuai sasaran dan seperti tidak terkontrol.

Koordinasi mata-tangan dalam olahraga tenis meja merupakan salah satu faktor yang sangat dibutuhkan bahkan sangat menentukan menang atau tidaknya pemain dalam mengikuti suatu pertandingan. Pemain yang memiliki koordinasi mata-tangan yang baik, akan mampu mengontrol bola dengan baik, dapat mengembalikan bola dalam posisi-posisi sulit baik backhand maupun forehand, misalnya bola yang mengarah kekanan dan berubah arah dengan memanfaatkan koordinasi mata-tangan dapat menambah respon untuk memukul bola.

Seperti dilihat dalam kegiatan latihan mata kuliah pilihan tenis meja, mahasiswa hanya berlatih teknik dasar saja seperti forehand tanpa mengetahui terlebih dahulu faktor-faktor yang juga ikut menentukan dalam peningkatan keterampilan forehand tersebut. Kebanyakan orang beranggapan bahwa di dalam bermain tenis meja yang harus kita kuasai hanya keterampilan dasar saja tanpa disertai unsur kondisi fisik.

Penelitian ini bertujuan untuk mengetahui hubungan antara koordinasi mata-tangan dengan ketepatan melakukan pukulan forehand dalam permainan tenis meja mahasiswa di FIK UNIMED.

Oleh karena itu, untuk membuktikan pernyataan tersebut maka penulis tertarik untuk melakukan penelitian dengan maksud ingin mengetahui sejauh manakah hubungan koordinasi mata-tangan terhadap ketepatan 
melakukan pukulan forehand permainan tenis meja pada mahasiswa FIK UNIMED.

\section{METODE}

Model yang digunakan dalam penelitian ini adalah penelitian deskriptif, dimana peneliti memaparkan hubungan koordinasi mata-tangan terhadap ketepatan fourhand tenis meja. (Moleong, 2000) mengatakan bahwa penelitian deskriptif adalah suatu bentuk penelitian yang ditujukan untuk mendeskripsikan atau menggambarkan fenomena-fenomena yang ada, baik fenomena alamiah maupun rekayasa manusia. (Rizkeikurniawan, 2013) dalam penelitian menggunakan metode deskriptif yaitu dengan teknik pengumpulan data dengan melihat dan terjun langsung ke tempat penelitian untuk mengambarkan keadaan lapangan dengan apa adanya dalam mengumpulkan data penelitian untuk menjawab realita dilapangan.

\section{Lokasi Penelitian}

Penelitian ini berlokasi di Kota Medan, tepatnya di UNIMED yang menjadi subjek dalam penelitian ini, ukuran sampel diambil dari populasi dengan teknik acak sederhana dimana penelitian ini dilaksanakan pada mahasiswa PKO FIK Unimed dengan ukuran sampel 24 orang.

\section{Teknik Pengumpulan Data}

Pengumpulan data dilakukan dengan menggunakan tes terhadap subjek penelitian. Untuk mengumpulkan data peneliti menggunakan teknik tes dan pengukuran, tes merupakan alat ukur untuk memperoleh data atau informasi. Instrumen penilaian koordinasi matatangan dan ketepatan pukulan fourhand.

\section{Teknik Analisis Data}

Analisis data adalah proses mencari dan menyusun secara sistematis data yang diperoleh dari hasil tes, wawancara, catatan lapangan, dan dokumentasi, dengan cara mengorganisasikan data ke dalam kategori, menjabarkan ke dalam unit-unit, melakukan sintesa, menyusun kedalam pola, memilih mana yang penting dan yang akan dipelajari, dan membuat kesimpulan sehingga mudah dipahami oleh diri sendiri dan orang lain
(Sugiyono, 2009).

\section{HASIL DAN PEMBAHASAN Hasil Penelitian}

Deskripsi hasil penelitian dianalisis berupa gambaran umum variabel yang diteliti, yaitu ketepatan pukulan forehand tenis meja diberi lambang (Y), Kordinasi mata-tangan (X). Hasil perhitungan ketepatan pukulan forehand tenis meja berjumlah 24 mahasiswa sebagai sampel penelitian dideskripsikan dengan statistik deskriptif.

Tabel 1. Rangkuman Hasil Penelitian

\begin{tabular}{ccc}
\hline STATISTIK & X & Y \\
\hline Jumlah Sampel (n) & 24 & 24 \\
Nilai Maksimum & 81 & 54 \\
Nilai Minimum & 41 & 6 \\
Rentang & 40 & 48 \\
Median & 69 & 23 \\
Modus & 41 & 27 \\
Rata - Rata & 63,29 & 23,79 \\
Varians (S $\left.{ }^{2}\right)$ & 213,61 & 121,56 \\
Simpangan Baku (S) & 14,62 & 11,03 \\
\hline
\end{tabular}

(Sumber: Hasil Data Penelitian, 2015)

Hasil pengujian dengan analisis regresi

linear sederhana terhadap variabel kordinasi mata-tangan $(\mathrm{X})$ dalam menunjang ketepatan pukulan forehand tenis meja mahasiswa jurusan PKO FIK-Unimed (Y) menghasilkan koefisien arah regresi a sebesar 0,163 dan konstanta $\mathrm{b}$ sebesar 0,801 . Bentuk hubungan antara kedua variabel tersebut dapat dinyatakan oleh persamaan regresi $\hat{Y}=0,163$ $+0,801 \mathrm{X}$.

Untuk menguji keberartian dan linieritas koefisien regresi pada persamaan $\hat{Y}$ 
$=0,163+0,801 \mathrm{X}$ digunakan dengan analisis varians (ANAVA) uji-F dimana kriteria keberartian jika Fhitung lebih besar dari Ftabel maka persamaan regresinya tersebut dinyatakan berarti sedangkan kriteria uji linier, jika Fhitung lebih kecil dari Ftabel maka persamaan regresi tersebut dinyatakan linier. Dari hasil pengujian keberartian model regresi tersebut diperoleh Fhitung > Ftabel $(4,40>4,30)$ sehingga dapat disimpulakan bahwa model persamaan regresi $\hat{Y}=0,163+$ $0,801 \mathrm{X}$ adalah berarti dengan demikian model regresi tersebut dapat digunakan. Selanjutnya pada hasil pengujian linieritas persamaan regresi $\hat{Y}=0,163+0,801 X$ dengan analisis varians dapat disimpulkan bahwa persamaan regresi tersebut adalah linier dimana Fhitung < Ftabel $(0,79<3,23)$. Hasil dari analisis tersebut dapat dilihat pada tabel 2. dibawah ini:

Tabel 2. Analisis Varians (ANAVA) antara $X$ dan $Y$

\begin{tabular}{|c|c|c|c|c|c|}
\hline $\begin{array}{l}\text { Sumber } \\
\text { Varians }\end{array}$ & dk & $\begin{array}{c}\text { Jumlah } \\
\text { Kuadrat } \\
\text { (JK) }\end{array}$ & $\begin{array}{c}\text { Rata- } \\
\text { Rata } \\
\text { Jumlah } \\
\text { Kuadrat } \\
\text { (RJK) }\end{array}$ & $\mathbf{F}_{\text {hitung }}$ & $\overline{F_{\text {tabel }}}$ \\
\hline Total & 24 & 16381,00 & $\overline{---}$ & & \\
\hline $\begin{array}{l}\text { Regresi } \\
\text { (a) }\end{array}$ & 1 & 13585,04 & --- & 4,40 & 4,30 \\
\hline $\begin{array}{l}\text { Regresi } \\
\text { b/a }\end{array}$ & 1 & 465,76 & 465,76 & & \\
\hline
\end{tabular}

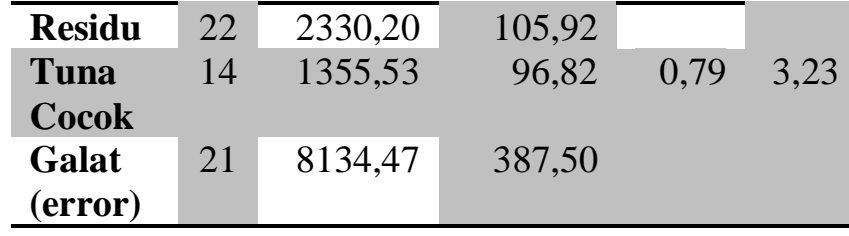

(Sumber: Hasil Data Penelitian, 2015)

Hasil perhitungan koefisien korelasi (ry1) dengan menggunakan product moment dilakukan setelah pengujian signifikansi dan uji kelinieran.

Tabel 3. Koefisien Korelasi dan Uji Signifikansi Antara X dan Y

\begin{tabular}{cccccc}
\hline $\begin{array}{c}\text { Korela } \\
\mathbf{s i}\end{array}$ & $\boldsymbol{\alpha}$ & $\mathbf{r}$ & $\mathbf{K D}$ & $\begin{array}{c}\mathbf{t}_{\text {hitun }} \\
\mathbf{g}\end{array}$ & $\begin{array}{c}\mathbf{t}_{\text {tabe }} \\
\mathbf{1}\end{array}$ \\
\hline $\mathbf{X}$ dan & 0,0 & 0,408 & 16,66 & 2,10 & 2,0 \\
$\mathbf{Y}$ & 5 & 1 & $\%$ & & 7 \\
\hline
\end{tabular}

(Sumber: Hasil Data Penelitian, 2015)Dari hasil

perhitungan statistik antara koefisien korelasi antara koordinasi mata-tangan (X) dengan ketepatan pukulan forehand tenis meja mahasiswa jurusan PKO FIK-Unimed (Y) sebagaimana terlihat pada tabel 4.8 diperoleh sebesar 0,4081 yaitu mempunyai hubungan yang cukup kuat. Koefisien determinasi sebesar $16,66 \%$ menjelaskan bahwa koordinasi matatangan (X) memberikan pengaruh sebesar $16,66 \%$ terhadap ketepatan pukulan forehand tenis meja sedangkan $83,34 \%$ dipengaruhi oleh variabel lain. Untuk mengetahui apakah hubungan antara koordinasi mata tangan (X) dengan ketepatan pukulan forehand tenis meja

(Y) signifikan atau tidak maka digunakan rumus uji - t. Dari hasil perhitungan diperoleh nilai 
$\mathrm{t}_{\text {hitung }}=2,10$. Pada taraf $\alpha=0,05$ dan $\mathrm{dk}=\mathrm{n}-2=$ 22, Dari daftar distribusi $t$ dengan menggunakan peluang $\alpha=0,95$ dengan diperoleh harga $t_{(22 ; 0,95)}=2,07$. Dalam kriteria pengujian hipotesis dua arah dinyatakan bahwa $t_{\text {Hitung }}>t_{\text {Tabel }}$ pada dimana $(2,10>2,07)$ sehingga dapat disimpulkan bahwa terdapat hubungan yang signifikan dari pada koordinasi mata tangan (X) terhadap ketepatan pukulan forehand tenis meja (Y).

\section{Pembahasan}

Pada hipotesis penelitian ini dikatakan bahwa terdapat hubungan yang signifikan antara koordinasi mata-tangan (X) dengan ketepatan pukulan forehand tenis meja (Y) pada mahasiswa PKO Unimed. Berdasarkan hasil pengujian hipotesis mengenai hubungan antara kedua variabel terbukti dimana terdapat hubungan yang signifikan, hasil koefisien korelasi ( $\left.\mathbf{r}_{\mathbf{y} . \mathbf{x}}\right)$ sebesar 0,4081 dengan koefisien determinasi sebesar $16,66 \%$. Hal ini berarti koordinasi matatangan mempunyai hubungan yang cukup kuat. Koordinasi mata-tangan juga dapat mempengaruhi ketepatan pukulan forehand tenis meja sebesar $16,66 \%$ sedangkan $83,34 \%$ ditentukan oleh variabel yang lain. Dengan memiliki kemampuan koordinasi mata-tangan yang baik maka ketepatan pukulan forehand tenis meja akan baik pula.
Hal ini disebabkan karena pada saat melakukan pukulan forehand tenis meja diperlukan timing yang tepat. Pada saat melakukan pukulan forehand diperlukan konsentrasi yang tinggi dimana waktu pelaksaanaan pukulan forehand hanya dalam hitungan dibawah satuan waktu detik, sehingga perlu koordinasi yang baik untuk dapat menganalisis bola, mulai dari arah bola datang, kecepatan bola datang, putaran bola datang dan ketinggian bola yang datang sehingga pemain bisa mengambil keputusan melakukan pukulan pukulan forehand terhadap bola yaitu menyimpulkan, arah bola yang akan dibuat, kecepatan, ketinggian dan juga putaran bola. Tentu dalam melakukan itu semua dibutuhkan kerjasama antara mata yang memberikan respon terhadap otak yaitu melihat situasi yang terjadi sebelum bola datang, otak berfungsi untuk mencerna informasi yang masuk dari mata dan menyimpulkan aksi yang paling baik yang akan dilakukan oleh otot. Setelah otak menyimpulkan aksi dari segala kemungkinan yang terjadi maka otak memerintahkan otot yang berperan melakukan aksi terhadap pukulan forehand lalu dengan segera aksi tersebut terlaksana. Berhasil tidaknya aksi yang telah disimpulkan otak sangat 
bergantung kepada tingkat koordinasi antara mata tangan yang dimiliki. Koordinasi adalah bentuk kondisi fisik yang dimiliki oleh seseorang dimana untuk dapat memiliki koordinasi yang tinggi membutuhkan latihan yang cukup. Dalam melakukan forehand tennis meja koordinasi yang tinggi sangat dibutuhkan sehingga gerakan antara apa yang telah diputuskan oleh otak dan dilakukan oleh tangan bisa sinkron. Hal tersebut terbukti bahwa hasil penelitian menunjukkan terdapat hubungan yang singifikan antara koordinasi mata-tangan terhadap ketepatan pukulan forehand tenis meja.

\section{KESIMPULAN}

Hasil pengujian hipotesis yang diajukan terbukti bahwa secara parsial maupun secara simultan variabel kordinasi mata-tangan, fleksibilitas pergelangan tangan dan motivasi belajar mempengaruhi ketepatan pukulan forehand tennis meja pada mahasiswa jurusan kepelatihan FIK Unimed. Terdapat hubungan yang signifikan antara kordinasi mata-tangan dengan ketepatan pukulan forehand tenis meja dengan kata lain semakin baik kemampuan koordinasi mata-tangan memiliki kecenderungan dapat meningkatkan ketepatan pukulan forehand tenis meja.

\section{DAFTAR RUJUKAN}

Achmad Sofyan Hanif, Model Pembelajaran Permainan Tenis Meja. Jakarta: Bumi Timur Jaya, 2011.

Adang Suherman, Dasar-dasar Penjaskes. Jakarata: Departemen Pendidikan dan Kebudayaan Direktorat Jenderal Pendidikan Dasar dan Menengah, 2000.
Agus Salim, Buku Pintar Tenis Meja, Bandung: NUANSA, 2008.

Agus Widarjono, Analisis Statistika Multivariat Terapa, Yogyakarta: YKPN, 2010.

Alex Kertamanah, Teknik dan Taktik Mahir Permainan Tenis Meja. Jakarta: PT Raja Grafindo Persada, 2003.

Andi Akbar, Latihan Kondisi Fisik Cabang Olahraga Tenis Meja, 2013 .online. http://akbarsportunm.blogspot.com (diakses 12 Februari 2015).

Anita J. Harrow, A Taxonomy of the psychomotor domain. New York: Longman Inc., 2002.

Arie S Sutopo, Alma Permana Lestari W, Buku Penuntun Praktikum Ilmu Faal Kerja. Jakarta: FIK UNIVERSITAS NEGERI JAKARTA, 2006.

Arma Abdoellah, Olahraga Untuk Perguruan Tingg. Jakarta: Sastra Hudaya, 2006.

Haryanto, J., \& Amra, F. (2020). The relationship of concentration and eyehand coordination with accuracy of backhand backspin serve in table tennis. International Journal of Technology, Innovation and Humanities, 1(1), 51-56.

Harsuki, Perkembangan Olahraga terkini Kajian Para Pakar, Jakarta: Raja Grafindo Persada. 2003.

Ika Rudi Mahendra, Prapto Nugroho, dan Said Junaidi. Kelentukan Pergelangan Tangan Dan Koordinasi Mata-Tangan Dalam Pukulan Forehand Tenis Meja. http://journal.unnes.ac.id/sju/index.php/jss $\underline{\mathrm{f}}$ (diakses pada 15 Maret 2015)

Ismaryati, Tes Dan Pengukuran Olahraga, Surakarta: LPP UNS dan UNS, 2009.

Kurniawan, R. (2013). PERSEPSI ORANG TUA TERHADAP SEKOLAH SEPAKBOLAPTP. WILAYAH I SUMUT TAHUN 2013 (Doctoral dissertation, UNIMED).

Kertamanah, Alex, Teknik dan Taktik Mahir Permainan Tenis Meja, Jakarta: PT Raja Grafindo Persada, 2003. 


\section{Journal Physical Health Recreation}

Volume 1 Nomor 1 ; November 2020

e-ISSN : 2747- 013X

Larry Hodges, Tenis Meja. Terjemahan oleh Eri D. Nasution. Jakarta: PT Rajawali Grafindo Persada, 2002.

Richard M. Hadgetts, Modern Human Relation at Work cetakan ke-3. Orlanda: The Dryden Press. 2006.

Simpson, Peter, Teknik Bermain Pingpong, Bandung: Pioneer Jaya, 2008.

Sudrajat Prawirasaputra, Rusli Lutan dan Ucup Yusup, Dasar-dasar Kepelatihan. Jakarta: Depdikbud Dirjen Pendidikan Dasar dan Menengah, 2000.

Suharno H.P., Ilmu Coaching Umum. FPOK IKIP: Jogjakarta, 2003. 